\title{
Altıncı Sınıf Öğrencilerinin Öz Bildirime Dayalı Sağlık Düzeyleri İçin Bir Belirleyici: Aile Sağlık Özellikleri $\infty$
}

\author{
Erdal AKDENIZ' ${ }^{1}$, Deniz KOÇOĞLU TANYER ${ }^{2}$
}

\section{Öz}

Amaç: Bu çalışma, öğrencilerin öz bildirimlerine dayalı sağlık düzeyleri ile özellikle aile sağlık öyküsü olmak üzere; sosyodemografik özellikler, sağlık durumu ve akademik özellikler gibi değişkenlerin ilişkisini incelemek amacıyla yapılmıştır.

Gereç ve Yöntem: Tanımlayıcı-ilişkisel türdeki çalışma için Konya kent merkezinde kura ile belirlenen iki okuldaki toplam 664 öğrenci araştırma kapsamına alınmıştır. Araştırmada veriler, araştırmacılar tarafından oluşturulan anket formu ile sınıf ortamında toplanmıştır. Veriler sayı ve yüzde olarak özetlenmiş ve değerlendirilmesinde KiKare testi kullanılmıştır.

Bulgular: Erkek öğrencilerin, üç ve üzeri kardeşe sahip olanların, doktor tarafından tanısı konulmuş kronik hastalığı olanların, sürekli ilaç kullananların, hastanede yatma ve ameliyat olma öyküsü olanların, herhangi bir kaza geçirenlerin ve şu anda var olan bir sağlık sorunu olanların, okul memnuniyeti ve okul başarısı düşük olanların öz bildirime dayalı sağlık algılarının daha olumsuz olduğu bulunmuştur. Aile özelliklerine bakıldığında algılanan ekonomik durumunu orta/kötü algılama ve geniş aile yapısı; annenin, babanın, kardeşin, büyükanne/ büyükbabanın ise çeşitli sağlık sorunlarının bulunması, öz bildirime dayalı sağıık düzeyi üzerinde olumsuz etkisi olan değişkenlerdir $(p<0.05)$.

Sonuç: Sosyodemografik özelliklerin, öğrencinin kendi ve ailesinin bazı sağlık özelikleri ve öğrencinin okul ile ilgili özelliklerinin öz bildirime dayalı sağıı algısını etkilediği bulunmuştur.

Anahtar kelimeler: Aile sağlığı, okul sağlığı, öğrenciler, sağlık düzeyi.

\begin{abstract}
A Determinant for Self-Reported Health Level of Sixth

Grade Students: Family Health

Aim: The aim of this study was to investigate the relationship between self-reported health level of students and family health history, sociodemographic characteristics, health status and academic characteristics.

Material and Methods: A total of 664 students from two schools determined by lot in Konya city center were included in this descriptive-relational type of study. The data were collected in the classroom environment by a questionnaire form developed by the researchers. Numbers, percentages and Chi-Square test was used in data analysis.

Results: It was determined that the perceptions of health based on self-report were more negative in students who are male, have three or more siblings, have a chronic disease, use continuous medication, have a history of surgery and hospitalization, had an accident, have a health problem and have low school satisfaction and school success. When the family characteristics were examined, it was found that the perception of the economic situation as moderate / bad, having a large family structure, and having various health problems of the mother, father, sibling or grandparents had a negative effect on the self-reported health level $(p<0.05)$.

Conclusion: It was found that sociodemographic characteristics, some of the health characteristics of the students and his / her families and the characteristics of the students related to the school affect the self-reported health perception.

Keywords: Family health, health status, school health, students.
\end{abstract}

\footnotetext{
1 Öğr. Gör. Kırşehir Ahi Evran Üniversitesi, Sağlık Bilimleri Fakültesi, Halk Sağlığı Hemşireliği Anabilim Dalı, Kırşehir, Türkiye, E-mail: erdalakdeniz@ahievran.edu.tr, Tel: 05418719378, ORCID: 0000-0001-7366-4017

${ }^{2}$ Doç. Dr. Selçuk Üniversitesi, Hemşirelik Fakültesi, Halk Sağlığı Hemşireliği Anabilim Dalı, Konya, Türkiye, E-mail: deniz.kocoglu@selcuk.edu.tr Tel: 0 505 86186 22, ORCID: 0000-0001-9496-8749

Geliş Tarihi: 22 Ağustos 2019, Kabul Tarihi: 7 Ocak 2020

Atıf/Citation: Akdeniz E, Koçoğlu Tanyer D. Altıncı Sınıf Öğrencilerinin Öz Bildirime Dayalı Sağlık Düzeyleri İçin Bir Belirleyici: Aile Sağlık Özellikleri. Hacettepe Üniversitesi Hemşirelik Fakültesi Dergisi 2020; 7(1): 31-40. DOI: 10.31125/ hunhemsire.715054
} 


\section{GíRiş}

Sağlık kavramı, bireylerin günlük yaşantıdaki rolleri, tecrübeleri, bilgi düzeyleri, değer yargıları ve beklentileri ile biçimlenmektedir. Kültürden kültüre farklılık gösteren sağlık; sosyal, kültürel, ekonomik, fiziksel ve biyolojik faktörlerden etkilenir ${ }^{1,2}$. Sağlık kavramı subjektif ve objektif olarak ikiye ayrılır. Subjektif olarak sağlık; bireyin kendini fiziksel, sosyal ve ruhsal olarak sağlıklı hissetmesidir. Objektif olarak sağlık ise yapılan tıbbi testlerin sonucuna göre hastalık durumunun olmamasıdır. Bir bireye sağlıklı diyebilmek için subjektif ve objektif olarak sağlıklı olması gerekmektedir ${ }^{3}$.

Öz bildirime dayalı subjektif sağlık algısını ölçmek için çoğunlukla bireye bir soru sorulur ve bireyden sağlığını kötü, orta, iyi veya mükemmel şeklinde ifade etmesi istenir ${ }^{4-7}$. Sağlık algısı; sağlığın değerlendirmesinde, ölçülmesinde ve geliştirilmesinde çok yaygın kullanılmaktadır. Sağlıklı yaşam biçimi davranışları kazandırmaya yönelik girişimlerden önce, bireylerin öz bildirime dayalı sağlık düzeyinin olumlu olması bireylerde olumlu davranışların ortaya çıkmasında önemli bir yer edinmektedir ${ }^{8}$. Bu nedenle sağlık algısı, bireye sağlıklı yaşam davranışlarının kazandırılması ve sürdürülmesini amaçlayan sağlığın geliştirilmesi süreci ile doğrudan ilişkilidir ${ }^{9}$. Sağlık algısı, sağlığın ölçülmesinin yanı sıra tıpkı yetişkinlerde olduğu gibi çocukların sağlık davranışlarının geliştirilmesi üzerinde rolü önemli olan bir kavram olarak düşünülmelidir.

Sağlık algısı ile ilgili çalışmaların önemli bir kısmı yetişkinler üzerinedir ve genel olarak bakıldığında çocukların kendi sağlık düzeyi ve bunu etkileyen faktörlerle ilgili çalışma sayısı da oldukça sınırlı olarak belirlenmiştir ${ }^{10-13}$. Bir çalışmada çocukların sağlıklarını çoğunlukla 'mükemmel' veya 'iyi' olarak algıladıkları; ağrı, depresyon ve okula uyumlarının bu algıyı etkilediği, bebeklik dönemine ait özelliklerin çok belirleyici olmadığı belirlenmiştir ${ }^{10}$. Riley (2004) de benzer şekilde çocukların okula karşı olumsuz tutumları ile sağlık düzeyini kötü algılama arasında bir ilişki olduğunu göstermiştir ${ }^{12}$. Ayrıca hem yetişkinler hem de çocuklar üzerine yapılan çalışmalarda konut tipi, depresyon, sigara kullanma, spor yapma, sağlık sorunu yaşama gibi sağlık algısının belirleyicilerinin de çok az değerlendirildiği görülmektedir7,14-18. Özellikle çalışmalarda aile sağlığının yeterince değerlendirilmediği dikkat çekmektedir. Ailenin sağlık durumu, sağlık alışkanlıkları, ekonomik olanakları, eğitim düzeyleri, sosyo-kültürel özellikleri, içinde yaşadıkları ortamın koşulları çocuğun sağlığını etkileyen önemli bir çevre kabul edilmelidir ${ }^{19}$. Bu nedenle özellikle aile sağlık özelliklerinin öğrencilerin öz bildirime dayalı olarak tanımlanan sağlık düzeyleri üzerine etkisinin incelenmesine gereksinim bulunmaktadır.

\section{YÖNTEM}

\section{Araştırmanın Amacı ve Araştırmanın Türü}

Bu araştırma öğrencilerin öz bildirimlerine dayalı sağlık düzeyleri ile özellikle aile sağlık öyküsü olmak üzere sosyodemografik özellikler, sağlık durumu ve akademik özellikler gibi değişkenlerin ilişkisini incelemek amacı ile tanımlayıcı-ilişkisel türde planlanmıştır.

\section{Araştırmanın Yeri ve Zamanı}

Konya ilinde bulunan ve kura sonucunda belirlenen iki ortaokulda çalışma yürütülmüştür. Veriler; araştırmacı tarafından Ocak 2015 tarihinde toplanmıştır.

\section{Araştırmanın Evreni ve Örneklemi}

Araştırmanın evrenini A ortaokulunda eğitim gören 674 altıncı sınıf öğrencisi ile B ortaokulunda eğitim gören 510 altıncı sınıf öğrencisi olmak üzere toplam 1184 öğrenci oluşturmaktadır. Araştırmaya altıncı sınıf öğrencilerinin alınmasının nedeni; algılanan sağlığı yaş itibariyle ilkokul öğrencilerinden daha iyi ifade edebilecekleridir. Ayrıca algılanan sağlığı ailelerinden ve arkadaşlarından bağımsız olarak kendilerinin bildirebileceğinin düşünülmesidir. Daha erken yaşlarda soyut düşünme süreci başlamadığından öğrencilerde sağlık durumu ile ilgili tam bir değerlendirme yapamayacakları varsayılabilir. Ayrıca adölesan dönemde öğrencinin kendini değerlendirmesi sağlıktan çok beden imajı üzerinden olacağı düşünülebilir.

Sağlığını orta-kötü değerlendirme algısı \%10 olarak belirlenen bir çalışmadan ${ }^{20}$ yola çıkarak bu oranı 0.03 kadarlık mutlak yüzde içinde \%99güvenle kestirmek için gerekli örneklem büyüklüğü Dünya Sağlık Örgütü yayını olan "p" yi " $d$ " kadarlık mutlak yüzde içinde \%99 güvenle kestirmek için gerekli örneklem büyüklüğü isimli hazır tablodan 664 olarak belirlenmiştir ${ }^{21}$. Örnek grubun belirlenmesinde tabakalı örneklem metodundan yararlanılmıştır. A okulunun tabaka ağırlığı 0.57; B okulun ise 0.43 olarak belirlenmiştir. A okulundan 378 öğrenci B okulundan ise 286 öğrenci çalışmaya dahil edilmiştir.

\section{Araştırmanın Değişkenleri}

Araştırmanın bağımlı değişkeni öğrencilerin öz bildirimlerine dayalı sağlık düzeyi, bağımsız değişkenleri ise; sosyodemografik özellikler, çocuğun sağlık durumu ve okul ile ilişkisi, çocuğun aile özellikleri ve aile sağlık özellikleridir.

\section{Veri Toplama Aracı ve Özellikleri}

Verilerin toplanmasında beş bölümden oluşan anket formu kullanılmıştır. Anket formu çocuğun sosyo-demografik (5 soru), sağlık durumu ( 6 soru), okulla olan ilişkisi ( 2 soru), öğrencinin sağlık algısı (1 soru), öğrencinin aile ve aile sağlık özellikleri ile ilgilidir (20 soru). Sosyodemografik özelliklerle ilgili sorular; yaş, cinsiyet, gidilen okul, kardeş sayısı, ailede kaçıncı çocuk olduğudur. Sağlık durumu ile ilgili sorular; kronik bir hastalığının olup olmadığı, sürekli kullandığı ilacın olup olmadığı, son bir yıl içinde hastanede yatma durumu ve ameliyat deneyimi, herhangi bir kaza geçirip geçirmediği, şuanda bir sağlık sorununun olup olmadığı gibi sorulardır. Okulla ilişkisini belirlemeye yönelik ise okul memnuniyeti ile okul başarısını değerlendiren sorular yer almıştır. Aile özellikleri ilgili sorularda; ailenin algılanan ekonomik durumu, anne ve babanın eğitim durumu ve aile yapısıdır. Aile sağlık öyküsünde ise doktor tarafından tanısı konulmuş kronik hastalığı olan, sürekli ilaç kullanan, son bir yıl içinde hastaneye yatan, son bir yıl içinde ameliyat olan, son bir yıl içinde sağlık semptomları (ağrı, kanama, uykusuzluk vb) olan, herhangi bir kaza geçiren olup olmadığı gibi sorular yöneltilmiştir. Aileyle ilgili değerlendirmeler "anne, baba, kardeş, büyükanne ve büyükbaba" için ayrı ayrı yapılmıştır. Türk geleneklerinde aile ilişkilerde büyükanne ve 
büyükbabanın önemli bir konumu olmasından dolayı çalışmada yer almıştır. Araştırmanın bağımlı değişkeni olan sağlık algısı 'mükemmel', 'iyi', 'orta', 'kötü' şeklinde seçeneklendirilmiştir.

\section{Verilerin Analizi}

Veriler araştırmacı tarafından sınıf ortamında toplanmıştır. Verilerin istatistiksel analizi için bilgisayar programından yararlanılmıştır. Veriler sayı ve yüzde olarak özetlenmiş ve ki-kare analizi kullanıımıştır.

\section{Araştırmanın Etik Yönü}

Araştırmada öğrenci ailelerine çalışmayla ilgili bilgi okul rehberlik servisi aracılığıyla ulaştırılmıştır. Öğrencilerden ise çalışma öncesi gerekli açıklama yapılarak onam alınmıştır. Araştırmaya başlamadan önce Konya il Milli Eğitim Müdürlüğü'nden kurum izni ve Selçuk Üniversitesi Sağlık Bilimleri Fakültesi Girişimsel Olmayan Klinik Araştırmalar Etik Kurulu Başkanlığı'ndan etik onay alınmıştır.

\section{BULGULAR}

Öğrencilerin \%69'u 12 yaşında \%17'si 11 yaşında ve \%51.2'si kızdır. \%36.3'ünün 2 kardeşi olup, \%38.6'sı ise ailede ilk çocuktur. Öğrencilerin \%4.5'inin kronik hastalığa sahip olduğu ve sürekli ilaç kullanan öğrencilerin oranının \%5.1 olduğu görülmektedir. Son bir yıl içinde hastanede yatan öğrencilerin oranı \%7.4; ameliyat olan öğrencilerin oranı \%2, kaza geçirenlerin oranı \%29.4; şuanda var olan bir sağlık sorunu olanların oranı ise \%15.4 olarak belirlenmiştir. Öğrencilerin okul ile ilişkilerinin dağılımına bakıldı̆̆ında; okulu çok sevenlerin\%48.8 ve sevenlerin oranı ise \%39.0' dır. Araştırma kapsamına alınan öğrencilerin \%43.1'i okul başarısına iyi, \%35.7'si ise çok iyi algıladığı görülmektedir. Araştırmaya katılan öğrencilerin $\% 44.5^{\prime} \mathrm{i}$ sağlığını mükemmel, \%38'i sağlığını iyi, \%15.2'si sağığını orta, \%2.3'ü sağlığını kötü olarak nitelendirmiştir.

Öz bildirime dayalı sağlık düzeyi ve öğrencilerin sosyodemografik özellikleri arasındaki ilişki incelendiğinde; öğrencilerin yaş $\left(\chi^{2}=1.744, p=.418\right)$, gidilen okul $\left(\chi^{2}=0.046\right.$, $p=.831)$, ailedeki kaçıncı çocuk olduğunun $\left(\chi^{2}=3.179\right.$, $p=.204)$ sağıık algısını değiştirmediği görülmektedir. Cinsiyete göre incelendiğinde kı öğrencilerin \%14.4'ü sağlığını 'orta/kötü' olarak algılarken, erkek öğrencilerde bu oranın \%20.7 olduğu görülmekte ve öz bildirime dayalı sağlık düzeyi ile cinsiyet arasındaki fark istatistik olarak anlamlıdır $\left(\chi^{2}=4.520, p<.05\right)$. Kardeş sayısı üç ve üzeri olan grupta sağlığını orta/kötü algılayanların oranının; iki ve altı olan gruba göre daha yüksek olduğu görülmektedir $\left(\chi^{2}=5.511\right.$, $\mathrm{p}<.05)$.

Kronik hastalığa sahip olan (\%43.3) öğrencilerin olmayanlara (\%16.2); sürekli ilaç kullanan (\%41.2) öğrencilerin kullanmayanlara (\%16.2); son bir yıl içinde hastanede yatanların (\%42.9) yatmayanlara (\%15.4); son bir yıl içinde ameliyat olanların (\%44.4) olmayanlara (\%16.7); herhangi bir kaza geçirenlerin (\%22.6) geçirmeyenlere (\%15.4) ve şu anda bir sağlık sorunu olanların (\%40.2) olmayanlara (\%13.3) göre sağlığını orta/kötü olarak değerlendirme oranları anlamlı bir şekilde yüksek bulunmuştur. Ayrıca okulu çok sevenlerin \%13.3' ünün sağlığını 'orta/ kötü' olarak algıladığı; okulu sevenlerin \%18.9'usağlığını 'orta/ kötü' olarak algıladığı; okulu az/ hiç sevmeyenlerin \%29.6' sının sağlığını 'orta/ kötü' olarak algıladığı görülmektedir ve fark istatistiksel açıdan önemlidir $\left(\chi^{2}=12.645\right.$, $\mathrm{p}<.05)$.Öğrencilerin okul başarısı ile öz bildirime dayalı sağlık düzeyi arasındaki ilişki incelendiğinde okul başarısı çok iyi olanların \%12.7'si sağlığı 'orta/ kötü' olarak algıladığı görülmektedir. Okul başarısı orta/ kötü olanların, \%27.7'si de sağlığını 'orta/ kötü' olarak algılamakta ve gruplar arasındaki fark anlamlı bulunmuştur $(p<.05)$ (Tablo 1$)$.

Tablo 1. Öğrencilerin Sağlık Durumları ve Bazı Okul Yaşantısı Özelliklerinin Öz Bildirime Dayalı Sağlık Düzeyine Göre Dağılımı $(\mathrm{n}=664)$

\begin{tabular}{|c|c|c|c|c|}
\hline \multicolumn{5}{|c|}{ Öz Bildirime Dayalı Sağlık Düzeyi } \\
\hline \multirow[b]{2}{*}{ Kronik hastalık } & \multicolumn{2}{|c|}{ Mükemmel /İyi } & \multicolumn{2}{|c|}{ Orta / Kötü } \\
\hline & $\mathrm{n}$ & $\%$ & $\mathbf{n}$ & $\%$ \\
\hline Var & 17 & 56.7 & 13 & 43.3 \\
\hline Yok & 531 & 83.8 & 103 & 16.2 \\
\hline \multicolumn{5}{|c|}{ Ki-kare ve $p$ değeri $\quad \chi^{2}=14.57 * p=.000$} \\
\hline \multicolumn{5}{|c|}{ Sürekli kullanılan ilaç } \\
\hline Var & 20 & 58.8 & 14 & 41.2 \\
\hline Yok & 528 & 83.8 & 102 & 16.2 \\
\hline \multicolumn{5}{|c|}{ Ki-kare ve $p$ değeri $\chi^{2}=13.968 \quad * p=.000$} \\
\hline \multicolumn{5}{|c|}{ Son bir yıl içinde hastanede yatma } \\
\hline Var & 28 & 57.1 & 21 & 42.9 \\
\hline Yok & 520 & 84.6 & 95 & 15.4 \\
\hline \multicolumn{5}{|c|}{ Ki-kare ve p değeri $\quad \chi^{2}=23.64 * p=.000$} \\
\hline \multicolumn{5}{|c|}{ Son bir yıl içinde ameliyat olma } \\
\hline Var & 10 & 55.6 & 8 & 44.4 \\
\hline Yok & 538 & 83.3 & 108 & 16.7 \\
\hline \multicolumn{5}{|c|}{$\begin{array}{ll}\text { Ki-kare ve p değeri } & * p=.006 \\
\text { Geçirilen herhangi bir kaza } & \end{array}$} \\
\hline Var & 151 & 77.4 & 44 & 22.6 \\
\hline Yok & 397 & 84.6 & 72 & 15.4 \\
\hline \multicolumn{5}{|c|}{ Ki-kare ve $p$ değeri $\quad \chi^{2}=4.969 * p=.02$} \\
\hline \multicolumn{5}{|c|}{ Şuanda var olan bir sağlık sorunu } \\
\hline Var & 61 & 59.8 & 41 & 40.2 \\
\hline Yok & 487 & 86.7 & 75 & 13.3 \\
\hline \multicolumn{5}{|c|}{ Ki-kare ve $p$ değeri $\quad \chi^{2}=43.170^{*} \mathrm{p}=.000$} \\
\hline \multicolumn{5}{|l|}{ Okul memnuniyeti } \\
\hline $\begin{array}{l}\text { Okulu çok } \\
\text { seviyorum }\end{array}$ & 281 & 86.7 & 43 & 13.3 \\
\hline Seviyorum & 210 & 81.1 & 49 & 18.9 \\
\hline $\begin{array}{l}\text { Az seviyorum /Hiç } \\
\text { sevmiyorum }\end{array}$ & 57 & 70.4 & 24 & 29.6 \\
\hline \multicolumn{5}{|c|}{ Ki-kare ve $p$ değeri $\quad \chi^{2}=12.645 * p=.002$} \\
\hline \multicolumn{5}{|l|}{ Okul başarısı } \\
\hline Çok iyi & 207 & 87.3 & 30 & 12.7 \\
\hline İyi & 239 & 83.6 & 47 & 16.4 \\
\hline Orta /Kötü & 102 & 72.3 & 39 & 27.7 \\
\hline Ki-kare ve $p$ değeri & & $173^{*}$ & $=.00$ & \\
\hline
\end{tabular}

Öğrencilerin aile özellikleri ile öz bildirime dayalı sağlık düzeyi arasındaki ilişki incelendiğinde algılanan ekonomik durumu çok iyi olanların \%15.4'ü; algılanan ekonomik durumu orta/kötü olanların \%28.3' ü sağlık düzeyini 'orta/kötü' olarak algılamaktadır ve fark anlamlıdır ( $p<.05)$. Aile yapısı çekirdek/ parçalanmış aile olan öğrencilerin sağlığını 'orta/ kötü' olarak algılama oranı; geniş ailesi olan öğrencilerden anlamlı bir şekilde düşüktür. ( $p<.05)$. Annenin 
eğitim durumu ( $p=.522)$, babanın eğitim durumu $(p=.483)$ ile ilgili grupların sağlık düzeyini 'mükemmel/iyi' ya da 'orta/kötü' olarak tanımlama oranlarının benzer olduğu görülmektedir (Tablo 2).

Tablo 2. Öğrencilerin Aile Özelliklerinin Öz Bildirime Dayalı Sağlık Düzeyine Göre Dağılımı ( $n=664)$

\begin{tabular}{|c|c|c|c|c|}
\hline Aile Özellikleri & \multicolumn{2}{|c|}{$\begin{array}{l}\text { Mükemmel } \\
\text { n }\end{array}$} & $\begin{array}{l}\text { Ort } \\
\mathrm{n}\end{array}$ & $\begin{array}{c}\text { ötü } \\
\%\end{array}$ \\
\hline \multicolumn{5}{|l|}{$\begin{array}{l}\text { Ailenin algılanan } \\
\text { ekonomik durumu }\end{array}$} \\
\hline Çok iyi & 143 & 84.6 & 26 & 15.4 \\
\hline İyi & 319 & 85.1 & 56 & 14.9 \\
\hline Orta /Kötü & 86 & 71.7 & 34 & 28.3 \\
\hline Ki-kare ve $p$ değeri & \multicolumn{4}{|c|}{$\chi^{2}=12.005 \quad{ }^{*} p=.002$} \\
\hline \multicolumn{5}{|l|}{ Annenin eğitim durumu } \\
\hline İlkokul ve altı & 200 & 81.3 & 46 & 18.7 \\
\hline Ortaokul ve üzeri & 423 & 82.0 & 93 & 18.0 \\
\hline Ki-kare ve $p$ değeri & \multicolumn{4}{|c|}{$\chi^{2}=0.410 \quad p=.522$} \\
\hline \multicolumn{5}{|l|}{ Babanın eğitim durumu } \\
\hline ilkokul ve altı & 125 & 84.5 & 23 & 15.5 \\
\hline Ortaokul ve üzeri & 423 & 82.0 & 93 & 18.0 \\
\hline Ki-kare ve $p$ değeri & \multicolumn{4}{|c|}{$\chi^{2}=0.492 \quad p=.483$} \\
\hline \multicolumn{5}{|l|}{ Aile yapısı } \\
\hline Çekirdek/Parçalanmış & 456 & 86.2 & 73 & 13.8 \\
\hline Geniş & 92 & 68.1 & 43 & 31.9 \\
\hline Ki-kare ve $p$ değeri & \multicolumn{4}{|c|}{$\chi^{2}=24.310$} \\
\hline
\end{tabular}

${ }^{*} \mathrm{p}<0.05$

Tablo 3'te anne, baba, büyükanne/büyükbabanın kronik hastalık tanısı alanların almayanlara göre sağlığını orta/kötü algılama oranları anlamlı bir şekilde yüksek bulunmuştur $(p<.05)$. Kardeşin kronik hastalığa sahip olmasının sağlık algısı üzerinde ilgisi bulunmamıştır ( $p>05)$. Ailede sürekli ilaç kullanma durumuna bakıldığında ise anne, baba, büyükanne/büyükbabanın sürekli ilaç kullananların kullanmayanlara göre sağlığını orta/kötü algılama oranları yüksektir. Annesi, büyükanne/büyükbabasının son bir yıl içinde hastaneye yatanların yatmayanlara göre sağlığını orta/kötü algılama oranları daha yüksektir $(p<.05)$. Son bir yıl içinde ameliyat olma durumuna bakıldığında ise anne, baba, kardeş büyükanne/büyükbabanın son bir yıl içinde ameliyat olanların olmayanlara göre sağlığını orta/kötü algılama oranları anlamlı bir şekilde yüksek bulunmuştur. Herhangi bir kaza geçirme durumunda ise kardeşi kaza geçirenlerin geçirmeyenlere göre sağlığını orta/kötü algılama oranları daha fazladır. Benzer şekilde kardeşin bulaşıcı hastalık geçirmesi durumunda da öğrencinin sağlığını orta/kötü algılama oranı yükselmektedir $(p<.05)$.

Anne, baba, kardeş, büyükanne/büyükbabasında sürekli ağrısı olanların olmayanlara göre sağlığını orta/kötü algılama oranları yüksektir. Baba ve büyükanne/büyükbabası sigara kullanan öğrencilerin sağığını orta/kötü algılama oranları daha fazladır $(p<.05)$. Anne ve babası uyku problemi yaşayan ve anne, baba, kardeş ya da büyükanne/büyükbabasında sürekli öfke sorunu olan öğrencilerde sağlığını orta/kötü algılama oranları daha yüksek görülmektedir $(p<.05)$. Anne, baba, kardeş ve büyükanne/büyükbabanın düzenli spor yapma durumunun sağlık algısı üzerinde ilgisi bulunmamıştır. Ayrıca anne, baba, kardeş, büyükanne/büyükbabası aşırı kilolu olan öğrencilerin olmayanlara göre sağlığını orta/kötü algılama oranları arasındaki fark anlamlıdır $(\mathrm{p}<.05)$.

\section{TARTIŞMA}

Bu çalışmada öncelikle öğrencilerin öz bildirime dayalı sağlık durumu incelenmiş ve sonrasında ilişkili olabilecek faktörler üzerinde durulmuştur. Çalışmada öğrencilerin\%15.2' si sağlığını orta, \%2.3'ü sağlığını kötü olarak nitelendirmiştir. Ergenlerde sağlık algısı ile ilgili yapılan bir çalışmada sağlığını orta ve kötü algılayanlar \%11.8 olarak bulunmuştur ${ }^{22}$. Okulda örgün eğitime devam edebilen öğrencilerin çoğunluğunun sağlık potansiyellerinin yüksek olduğu düşünüldüğünde sağlığını orta/kötü olarak nitelendirenlerin oranı yüksek kabul edilmelidir. Çalışmada öz bildirime dayalı sağlık düzeyi ile yaş, gidilen okul, çocuğun ailedeki doğum sırası arasında anlamlı bir ilişki bulunmamasına rağmen literatürde bu değişkenlerin anlamlı olduğunu gösteren çalışmalar vardır ${ }^{4,18,23-27}$. Yapılan çalışmalarda yaş arttıkça öz bildirime dayalı sağlık düzeyinin daha olumsuz olduğu belirlenmiştir ${ }^{18,27}$. Çalışmada yaş ile öz bildirime dayalı sağlık düzeyinin ilişkili olmaması çalışma grubunun benzer yaşta olmasından ve diğer yaş gruplarıyla karşılaştırma yapılmamasından kaynaklanıyor olabilir. Çalışmada öz bildirime dayalı sağlık düzeyi ile cinsiyet ve kardeş sayısı arasındaki fark anlamlı bulunmuştur. Erkek öğrencilerde ve daha fazla kardeşe sahip olanlarda sağlık düzeyini kötü/orta algılayanların oranı artmaktadır.

Türkiye'de ve Pakistan' da yapılan bir çalışmada kadınların erkeklere göre daha olumsuz sağlık algısına sahip oldukları belirlenmiştir ${ }^{15,17}$. Ancak bu çalışmada erkek çocuklarda öz bildirime dayalı sağlık düzeyine orta/kötü diyenler daha fazladır. Bu konuyla ilgili alanda yeterli çalışma olmadığı için cinsiyetin öz bildirime dayalı sağlık düzeyi üzerinde etkisini yorumlamak doğru olmayabilir. Erkek öğrencilerin kaza ve yaralanmalara kız öğrencilerden daha fazla maruz kalmaları nedeniyle farkın olduğu düşünülebilir.

Türkiye'de üniversite öğrencilerinin genel sağlık durumlarının bazı değişkenlere göre incelendiği çalışmada genel sağlık düzeyi puan ortalamaları ile kardeş sayısı arasında anlamlı bir ilişki bulunamamıştır ${ }^{28}$. Kardeş sayısının artması ile öğrencilerin sosyal destek algılarının olumsuz etkilendiğ $\mathrm{i}^{23}$, suç işleme davranışlarıyla kardeş sayısının ilgili olabileceği ${ }^{26}$, kardeş sayısının dört ve üzerinde çıkmasının aileden kaynaklı yaşam doyumunu düşürdüğü ${ }^{24}$, kardeş sayıları fazla olan çocukların idrar kaçırma probleminin fazla olduğ ${ }^{25}$ literatürde yer alan bazı bilgilerdir. Kişilik kuramcılarından Adler, kişilik özellikleri ile doğum sırası arasında ilişki olduğunu söylemektedir. Doğum sırasının çocuğun aile içerisindeki yeri hakkındaki algısını etkilediği ve bu nedenle en büyük (ilk çocuk), ortanca, en küçük (son çocuk) ve tek çocukların farklı kişilik eğilimleri geliştirdiklerini iddia etmiştir ${ }^{29}$. Bu nedenlerden dolayı öğrencilerin sağlık durumu incelenirken ve bu sağlık durumu ile aile arasında bağlantı araştırılırken kardeş sayısı ve kaçıncı sıradaki çocuk olduğu önemli bir değişken olarak yer almalıdır.

Çalışmada ayrıca kronik hastalığı olanların, sürekli ilaç kullananların, son bir yıl içinde hastanede yatanların, 
Tablo 3. Aile Bireylerinin Sağlık Özelliklerine Göre Öğrencilerin ÖzBildirime Dayalı Sağıık Düzeyinin Dağııııı

\begin{tabular}{|c|c|c|c|c|c|c|c|c|c|c|c|c|c|c|c|c|c|}
\hline \multirow[t]{3}{*}{ Aile Sağlık Özellikleri } & & \multicolumn{4}{|c|}{ Anne } & \multicolumn{4}{|c|}{ Baba } & \multicolumn{4}{|c|}{ Kardes } & \multicolumn{4}{|c|}{ Büyükanne/Büyükbaba } \\
\hline & & \multicolumn{2}{|c|}{ Mükemmel/iyi } & \multicolumn{2}{|c|}{ Orta/Kötü } & \multicolumn{2}{|c|}{ Mükemmel/iyi } & \multicolumn{2}{|c|}{ Orta/Kötü } & \multicolumn{2}{|c|}{ Mükemmel/ìyi } & \multicolumn{2}{|c|}{ Orta/Kötü } & \multicolumn{2}{|c|}{ Mükemmel/ìyi } & \multicolumn{2}{|c|}{ Orta/Kötü } \\
\hline & & $\mathrm{n}$ & $\%$ & $\mathrm{n}$ & $\%$ & $n$ & $\%$ & $n$ & $\%$ & $n$ & $\%$ & $n$ & $\%$ & $\mathrm{n}$ & $\%$ & $\mathrm{n}$ & $\%$ \\
\hline \multirow[t]{3}{*}{ Kronik hastalık } & Var & 67 & 68.4 & 31 & 31.6 & 63 & 72.4 & 24 & 27.6 & 24 & 85.7 & 4 & 14.3 & 130 & 71.8 & 51 & 28.2 \\
\hline & Yok & 481 & 85.0 & 85 & 15.0 & 485 & 84.1 & 92 & 15.9 & 524 & 82.4 & 112 & 17.6 & 418 & 86.5 & 65 & 13.5 \\
\hline & & \multicolumn{4}{|c|}{$\chi^{2}=15.995 \quad \mathrm{p}=.000$} & \multicolumn{4}{|c|}{$\chi^{2}=7.106 \quad \mathrm{p}=.008$} & \multicolumn{4}{|c|}{$\chi^{2}=\quad p=.803$} & \multicolumn{4}{|c|}{$\chi^{2}=19.785 \quad \mathrm{p}=.000$} \\
\hline \multirow[t]{3}{*}{ Sürekli ilaç kullanma } & Var & 64 & 63.4 & 37 & 36.6 & 55 & 69.6 & 24 & 30.4 & 28 & $\frac{\lambda}{71.8}$ & 11 & 28.2 & 109 & 74.1 & 38 & 25.9 \\
\hline & Yok & 484 & 86.0 & 79 & 14.0 & 493 & 84.3 & 92 & 15.7 & 520 & 83.2 & 105 & 16.8 & 439 & 84.9 & 78 & 15.1 \\
\hline & & \multicolumn{4}{|c|}{$\chi^{2}=30.342 \quad p=.000$} & \multicolumn{4}{|c|}{$\chi^{2}=10.365 \quad \mathrm{p}=.001$} & \multicolumn{4}{|c|}{$\chi^{2}=3.312 \quad \mathrm{p}=.069$} & \multicolumn{4}{|c|}{$\chi^{2}=9.197 \quad \mathrm{p}=.002$} \\
\hline \multirow[t]{3}{*}{ Hastaneye yatma } & Var & 30 & 69.8 & 13 & 30.2 & 16 & 66.7 & 8 & 33.3 & 36 & 83.7 & 7 & 16.3 & 53 & 66.2 & 27 & 33.8 \\
\hline & Yok & 518 & 83.4 & 103 & 16.6 & 532 & 83.1 & 108 & 16.9 & 512 & 82.4 & 109 & 17.6 & 495 & 84.8 & 89 & 15.2 \\
\hline & & \multicolumn{4}{|c|}{$\chi^{2}=5.194 \quad p=.023$} & \multicolumn{4}{|c|}{$\chi^{2}=p=.051$} & \multicolumn{4}{|c|}{$\chi^{2}=0.045 \quad \mathrm{p}=.832$} & \multicolumn{4}{|c|}{$\chi^{2}=16.721 \quad \mathrm{p}=.000$} \\
\hline \multirow[t]{3}{*}{ Ameliyat olma } & Var & 21 & 63.6 & 12 & 36.4 & 23 & 67.6 & 11 & 32.4 & 19 & 65.5 & 10 & 34.5 & 41 & 63.1 & 24 & 36.9 \\
\hline & Yok & 527 & 83.5 & 104 & 16.5 & 525 & 83.3 & 105 & 16.7 & 529 & 83.3 & 106 & 16.7 & 507 & 84.6 & 92 & 15.4 \\
\hline & & \multicolumn{4}{|c|}{$\chi^{2}=8.598 \quad \mathrm{p}=.003$} & & $x^{2}=5.50$ & $\mathrm{p}=. \mathrm{C}$ & & & $x^{2}=6.0$ & $\mathrm{p}=.0$ & & & $x^{2}=18.9$ & & \\
\hline Kaza geçirme & Var & 20 & 80.0 & 5 & 20.0 & 43 & 78.2 & 12 & 21.8 & 43 & 72.9 & 16 & 27.1 & 14 & 73.7 & 5 & 26.3 \\
\hline & Yok & 528 & 82.6 & 111 & 17.4 & 505 & 82.9 & 104 & 17.1 & 505 & 83.5 & 100 & 16.5 & 534 & 82.8 & 111 & 17.2 \\
\hline & & & $\chi^{2}=$ & $\mathrm{p}=.7$ & & & $\chi^{2}=0.7$ & $\mathrm{p}=.3$ & & & $x^{2}=4.1$ & $\mathrm{p}=.0$ & & & $\chi^{2}=$ & $p=.352$ & \\
\hline Bulaşıcı hastalık geçirme & Var & 33 & 73.3 & 12 & 26.7 & 22 & 73.3 & 8 & 26.7 & 55 & 70.5 & 23 & 29.5 & 8 & 80.0 & 2 & 20.0 \\
\hline & Yok & 515 & 83.2 & 104 & 16.8 & 526 & 83.0 & 108 & 17.0 & 493 & 84.1 & 93 & 15.9 & 540 & 82.6 & 114 & 17.4 \\
\hline & & & $\chi^{2}=2.83$ & $\mathrm{p}=$. & & & $\chi^{2}=1.84$ & $\mathrm{p}=.1$ & & & $\chi^{2}=8.8$ & $\mathrm{p}=.0$ & & & $\chi^{2}=$ & $p=.68 \mathrm{~s}$ & \\
\hline
\end{tabular}


Tablo 3. Aile Bireylerinin Sağlık Özelliklerine Göre Öğrencilerin ÖzBildirime Dayalı Sağlık Düzeyinin Dağılımı (devamı)

\begin{tabular}{|c|c|c|c|c|c|c|c|c|c|c|c|c|c|c|c|c|c|}
\hline \multirow[t]{3}{*}{ Aile Sağlık Özellikleri } & & \multicolumn{4}{|c|}{ Anne } & \multicolumn{4}{|c|}{ Baba } & \multicolumn{4}{|c|}{ Kardeş } & \multicolumn{4}{|c|}{ Büyükanne/Büyükbaba } \\
\hline & & \multicolumn{2}{|c|}{ Mükemmel/İyi } & \multicolumn{2}{|c|}{ Orta/Kötü } & \multicolumn{2}{|c|}{ Mükemmel/İyi } & \multicolumn{2}{|c|}{ Orta/Kötü } & \multicolumn{2}{|c|}{ Mükemmel/íyi } & \multicolumn{2}{|c|}{ Orta/Kötü } & \multicolumn{2}{|c|}{ Mükemmel/ìyi } & \multicolumn{2}{|c|}{ Orta/Kötü } \\
\hline & & $\mathrm{n}$ & $\%$ & $n$ & $\%$ & $\mathrm{n}$ & $\%$ & $n$ & $\%$ & $n$ & $\%$ & $n$ & $\%$ & $n$ & $\%$ & $n$ & $\%$ \\
\hline \multirow[t]{3}{*}{ Sürekli ağrısı olma } & Var & 48 & 58.5 & 34 & 41.5 & 20 & 51.3 & 19 & 48.7 & 8 & 57.1 & 6 & 42.9 & 44 & 68.8 & 20 & 31.2 \\
\hline & Yok & 500 & 85.9 & 82 & 14.1 & 528 & 84.5 & 97 & 15.5 & 540 & 83.1 & 110 & 16.9 & 504 & 84.0 & 96 & 16.0 \\
\hline & & \multicolumn{4}{|c|}{$\chi^{2}=37.355 \quad p=.000$} & \multicolumn{4}{|c|}{$\chi^{2}=28.061 \quad p=.000$} & \multicolumn{4}{|c|}{$p=.022$} & \multicolumn{4}{|c|}{$\chi^{2}=9.328 \quad \mathrm{p}=.002$} \\
\hline \multirow[t]{3}{*}{ Sigara kullanma } & Var & 54 & 77.1 & 16 & 22.9 & 278 & 79.7 & 71 & 20.3 & 32 & 80.0 & 8 & 20.0 & 18 & 58.1 & 13 & 41.9 \\
\hline & Yok & 494 & 83.2 & 100 & 16.8 & 270 & 85.7 & 45 & 14.3 & 516 & 82.7 & 108 & 17.3 & 530 & 83.7 & 103 & 16.3 \\
\hline & & \multicolumn{4}{|c|}{$\chi^{2}=1.575 \quad \mathrm{p}=.209$} & \multicolumn{4}{|c|}{$\chi^{2}=4.214 \quad \mathrm{p}=.040$} & \multicolumn{4}{|c|}{$\chi^{2}=0.189 \quad \mathrm{p}=.664$} & \multicolumn{4}{|c|}{$\chi^{2}=13.500 \quad \mathrm{p}=.000$} \\
\hline \multirow[t]{3}{*}{ Uyku problemi yaşama } & Var & 33 & 60.0 & 22 & 40.0 & 22 & 64.7 & 12 & 35.3 & 29 & 72.5 & 11 & 27.5 & 13 & 76.5 & 4 & 23.5 \\
\hline & Yok & 515 & 84.6 & 94 & 15.4 & 526 & 83.5 & 104 & 16.5 & 519 & 83.2 & 105 & 16.8 & 535 & 82.7 & 112 & 17.3 \\
\hline & & \multicolumn{4}{|c|}{$\chi^{2}=21.112 \quad \mathrm{p}=.000$} & \multicolumn{4}{|c|}{$\chi^{2}=7.896 \quad \mathrm{p}=.005$} & \multicolumn{4}{|c|}{$\chi^{2}=2.970 \quad p=.085$} & \multicolumn{4}{|c|}{$\chi^{2}=\quad p=.516$} \\
\hline \multirow[t]{3}{*}{ Sürekli öfkeli olma } & Var & 13 & 50.0 & 13 & 50.0 & 35 & 60.3 & 23 & 39.7 & 22 & 68.8 & 10 & 31.2 & 2 & 33.3 & 4 & 66.7 \\
\hline & Yok & 535 & 83.9 & 103 & 16.1 & 513 & 84.7 & 93 & 15.3 & 526 & 83.2 & 106 & 16.8 & 546 & 83.0 & 112 & 17.0 \\
\hline & & \multicolumn{4}{|c|}{$\chi^{2}=\quad p=.000$} & & $\chi^{2}=21$ & $p=$. & & & $\chi^{2}=4.4$ & $\mathrm{p}=.0$ & & & $x^{2}=$ & $b=.010$ & \\
\hline Spor yapma & Var & 103 & 82.4 & 22 & 17.6 & 115 & 83.9 & 22 & 16.1 & 143 & 79.9 & 36 & 20.1 & 11 & 84.6 & 2 & 15.4 \\
\hline & Yok & 445 & 82.6 & 94 & 17.4 & 433 & 82.2 & 94 & 17.8 & 405 & 83.5 & 80 & 16.5 & 537 & 82.5 & 114 & 17.5 \\
\hline & & & $\chi^{2}=0$. & $\mathrm{p}=$ & & & $\chi^{2}=0$ & $\mathrm{p}=.6$ & & & $\chi^{2}=1.1$ & $\mathrm{p}=.2$ & & & $\chi^{2}=$ & $=1000$ & \\
\hline Aşırı kilolu olma & Var & 24 & 68.6 & 11 & 31.4 & 18 & 62.1 & 11 & 37.9 & 12 & 60.0 & 8 & 40.0 & 34 & 63.0 & 20 & 37.0 \\
\hline & Yok & 524 & 83.3 & 105 & 16.7 & 530 & 83.5 & 105 & 16.5 & 536 & 83.2 & 108 & 16.8 & 514 & 84.3 & 96 & 15.7 \\
\hline & & & $x^{2}=4$ & $p=$. & & & $x^{2}=8$ & $p=. c$ & & & $x^{2}=$ & $\mathrm{p}=.014$ & & & $x^{2}=15$ & $\mathrm{p}=$. & \\
\hline
\end{tabular}


son bir yıl içinde ameliyat olanların, kaza geçirenlerin, sağlık sorunu bulunanların bulunmayanlara göre öz bildirime dayalı sağlık düzeyi daha olumsuz bulunmuştur (Tablo 1). Literatürde de hastalıkların kötü öz bildirime dayalı sağlık düzeyi ile ilişkili olduğunu saptamıştır ${ }^{30,31}$. Ayrıca Türkiye'de yapılan bir çalışmada da sağlık sorunlarının öz bildirime dayalı sağıık düzeyini olumsuz etkilediğisaptanmıştır4. Bu bulgu subjektif bir değerlendirme olan öz bildirime dayalı sağlık düzeyinin objektif sağlık düzeyi hakkında da bilgi veren önemli bir değerlendirme aracı olduğunu göstermesi bakımından da önemlidir.

Çalışmada; okulu az/hiç sevmeyenler ile okul başarısı orta/ kötü olanların öz bildirime dayalı sağlık düzeyi diğer gruplara kıyasla daha olumsuz bulunmuştur. Bu çalışma ile Kanada'da yapılan çalışmadaki sonuçlar benzer özelliktedir. Okuldan hoşlanmıyorum diyen öğrenciler ile öz bildirime dayalı sağlık düzeyine kötü diyen öğrenciler arasında anlamlı ilişki bulunmuştur ${ }^{12}$. Okul başarısı olumlu yönde arttıkça öz bildirime dayalı sağlık düzeyine orta/kötü diyenler azalmaktadır. Bu bulgulardan yola çıkarak bir neden sonuç ilişkisi kurulması olanaklı değildir. Öğrenciler okulu sevdikleri ve başarıları yüksek olduğu için mi sağlıklı hissediyorlar ya da sağlıklı oldukları için mi okul iletişimleri ve akademik başarıları yüksek bunun söylenmesi olası değildir. Ancak bu çalışma ve literatür göz önünde bulundurulursa sağlık ve akademik başarı arasında oldukça kuvvetli bir ilişki olduğu söylenebilir ${ }^{28,32,33}$. Ayrıca okulda sunulan sağlık hizmetlerinin akademik performans üzerinde etkisini değerlendiren çalışmalarda bu hizmetlerin devamsızlık, okula geç kalma durumu ve okuldaki disiplin sorunlarını azalttığı; mezun olan öğrenci sayısı ile akademik not ortalamasını artırdığı sonuçlarına ulaşıımıştır ${ }^{34}$. Okul hemşiresinin amaçlarından biri öğrencilerin akademik performansını artırmaktır. Bu nedenle okul sağlığı hemşiresi öğrenci ve okul arasındaki iletişimi geliştirmek, öğrencilerin okul başarısının artmasına yönelik (sınıftaki öğrenci sayısının azaltılması, görme, işitme sorunu olanların belirlenerek tedavilerinin sağlanması vb.) girişimlerde bulunmak; belediyeler, okul idaresi ile işbirliği içinde olarak okuldaki sosyal imkanları (park yapılması, futbol, basketbol sahası vb.) artırmak gibi uygulamalarla öğrencilerin okula karşı tutumlarını etkilemenin yanı sıra okullarda verilecek eğitim ve sağlık hizmetleriyle öğrencilerin sağlıklı yaşam alışkanlıkları edinmelerini sağlamak onların hem akademik başarılarını ${ }^{35,36}$ hem de öz bildirime dayalı sağlık düzeyini olumlu yönde değiştirebilir.

$\mathrm{Bu}$ çalışmada algılanan ekonomik durumunu orta/kötü algılayanlar ve geniş aile yapısına sahip olan öğrencilerin sağılı algıları diğer gruplara göre daha olumsuz özellikte bulunmuştur. Anne ve babanın eğitim durumu ile sağlık algısı arasında ilişki bu çalışmada kurulmamıştır. Dünyada ve Türkiye'de yapılan çalışmalarda öz bildirime dayalı sağlık düzeyi ile sosyoekonomik durumun ilişkili olduğunu saptanmıştır ${ }^{16,17,37-41}$. Yapılan çalışmalarda sosyoekonomik düzeyi düşük olan öğrencilerde daha yüksek oranda depresif belirti gözlendiği bil-dirilmektedir ${ }^{42,43}$. Bir çalışmada algılanan ekonomik durumun sağııkı yaşam biçimi davranışları üzerinde belirleyici olduğu saptanmıştı ${ }^{44}$. Başka bir çalışmada sosyoekonomik düzeyin aile sağlığı ve akademik başarıda etkili olduğu bulunmuştur ${ }^{45}$. Çalışmada anne/baba eğitim durumu ile öz bildirime dayalı sağ/ık düzeyi arasında ilişki bulunamamasına rağmen yapılan bazı çalışmalarda eğitim durumu ile öz bildirime dayalı sağlık düzeyi arasındaki ilişki açısından farklı sonuçlar elde edilmiş ve eğitim durumu ile öz bildirime dayalı sağlık düzeyi arasında pozitif ilişki saptanmıştır ${ }^{16,17,37,40,41,46}$. Eğitim seviyesi yükseldikçe yaşam tarzında ve ekonomik durumda farklılaşmalar olabilmekte bu duruma bağlı olarak da yaşam kalitesi yükselmekte, dolayısıyla da öz bildirime dayalı sağlık düzeyi yükselmektedir.

Ailenin sağlık özellikleri ile öğrencinin öz bildirime dayalı sağlık düzeyi arasındaki ilişki incelendiği zaman anne, baba, kardeş ve büyükanne/büyükbabanın çeşitli sağlık özelliklerine göre öğrencilerin öz bildirime dayalı sağlık düzeylerinin farklılaştığı belirlenmiştir. Annenin; doktor tarafından tanısı konulmuş kronik hastalığının olması, sürekli ilaç kullanması, son bir yıl içinde hastaneye yatmış olması, son bir yıl içinde ameliyat olması, sürekli ağrısı olması, uyku problemi yaşaması, sürekli öfkeli olması ve aşırı kilolu olması çocuğun öz bildirime dayalı sağlık düzeyini etkilemektedir (Tablo 3). Literatürde annenin çeşitli özelliklerinin çocuğun sağlığı ya da sosyal özelliklerini etkilediği ile ilgili çalışmalar bulunmaktadır. Davranış bozukluğu olan çocukların, annelerinde antisosyal davranış, histrionik davranış ve uyum bozukluğu sorunlarının daha yaygın olduğu bilinmektedir ${ }^{47}$. Türkiye'de yapılan bir çalışmada da sosyal alanda hiperaktif çocukların annelerinde daha fazla sosyal yeti yitimi olduğu saptanmıştır ${ }^{48}$. Annenin sağlık sorunları çocuğun sağlık algısını farklı nedenlerden dolayı etkilemiş olabilir. Annenin sağlık sorunu çocuklarına ayırdığı süre ve süreyi etkin kullanmayı olumsuz etkileyebilir. Özellikle hastanede yatma ya da sürekli olarak bazı semptomlara sahip olması bu ikili ilişkinin sağ ıksız gelişmesine neden olabilir. Annenin sağlık sorunu yaşaması çocuğun bakımı ile ilgili inmalleri de ortaya çıkarabilir. Bu durum hem çocuğun gelişim sorunlarına hem de baş etme mekanizmalarının yeterince gelişmemesi ile de sonuçlanabilir.

Babanın; doktor tarafından tanısı konulmuş kronik hastalığının olması, sürekli ilaç kullanması, son bir yıl içinde ameliyat olması, sürekli ağrısı olması, sigara kullanması, uyku problemi yaşaması, sürekli öfkeli olması ve aşırı kilolu olması çocuğun öz bildirime dayalı sağlık düzeyini etkilemektedir (Tablo 3). Literatürde de az sayıda olmakla birlikte baba ile çocuk sağlığı arasında ilişki kurulmuştur. Baba yoksunu olarak yaşayan çocukların kaygılarının, annebabasıyla yaşayan çocukların kaygılarından yüksek olduğu bilinmektedir ${ }^{49}$. Babasıyla iyi ilişkisi olan çocukların psikolojik olarak daha uyumlu çocuklar olduğu $\mathrm{u}^{50}$, babadaki depresyonun ise erkek çocuklarda sinirlilik, kontrol sorunlarına yol açabildiği belirtilmektedir ${ }^{51}$.

Kardeşin; son bir yıl içinde ameliyat olması, kaza geçirme durumu olması, bulaşıcı hastalık geçirmiş

olması, sürekli ağrısı olması, sürekli öfkeli olması ve aşırı kilolu olması çocuğun öz bildirime dayalı sağlık düzeyini etkilemektedir (Tablo 3). Yapılan bir çalışmada hasta çocuğu olan ailelerde ebeveynler hasta çocuk ile ilgilendiği için diğer çocuklarda yalnızlık, üzüntü ve anne-babaya ulaşmada 
güçlük çekme gibi duyguların yaşandığı vurgulanmaktadır. Ebeveynlerin sağlıklı çocuklardan beklentileri artmakta, anne-babanın sağlıklı çocuklara karşı toleransı azalmaktadır. Bütün bu durumların sağlıklı kardeşlerde olumsuz davranışlara neden olabileceği belirtilmektedir ${ }^{52}$. Kardeşler hastalık durumuna duyarlıdırlar ve hasta çocukla benzer stres yaşarlar. Bundan dolayı hastalık durumuna karşı bunalım, öfke, üzüntü, suçluluk duygusu ve sosyal izolasyon yaşayabilirler. Çalışmada da bundan dolayı öğrencilerin kardeşlerinde bulunan bazı sağlık sorunları nedeniyle öz bildirime dayalı sağlık düzeyleri olumsuz etkilenmiş olabilir. Büyükanne veya büyükbabanın; doktor tarafından tanısı konulmuş kronik hastalığının olması, sürekli ilaç kullanması, son bir yıl içinde hastaneye yatmış olması, son bir yıl içinde ameliyat olması, sürekli ağrısı olması, sigara kullanması, sürekli öfkeli olması ve aşırı kilolu olması öğrencinin öz bildirime dayalı sağlık düzeyini etkilemektedir (Tablo 3). Sağlığı bozulmuş ileri yaştaki yaşılıarın bakımı aile içinde "manevi yük" olarak kavramsallaştırılan sorunu ortaya çıkarabilir. Yaşlının bakımıyla ilgilenen ailenin yetişkin üyelerinin iş, eş ve çocuklarıyla iletişimi bozulabilir, birey ailesi ile baktığı yaşlı arasında sıkışıp kalabilir ${ }^{53}$.

Aile büyükleri, ebeveyn ve çocukların bir arada zaman geçirmesi "kuşaklararası iletişim" için mutlaka sağlanması gereken ortamlardır. Ancak aile sağlık özellikleri ile ilgili sonuçlar bize göstermektedir ki aile üyelerinin sağlık sorunları çocuğu yakından etkilemekte ve kendi sağlık algısının kötüleşmesine neden olmaktadır. Bu nedenle ailelerin çocukları yaşanılan sağlık sorunlarının yüklerinden koruması önemlidir. Oldukça büyük bir ergen grupla ( $n=32560)$ yapılan bir çalışma sonucunda da öz bildirime dayalı sağlık düzeyindeki sosyal eşitsizlikler ailelerin öznel ve nesnel refah düzeyleri ile güçlü bir bağlantı göstermiştir ${ }^{54}$.

\section{SONUÇ ve ÖNERILER}

Sonuç olarak öğrencinin sosyo demografik, okul, kendi ve ailesinin bazı sağlık özeliklerinin öz bildirime dayalı sağlık algısını etkilediği bulunmuştur. Erkek öğrencilerin, kardeş sayısı fazla olanların, sağlık sorunu bulunanların, okulla ilişkisi olumsuz olanların, okul başarısı düşük olanların, ekonomik durumunu kötü algılayanların, geniş ailede yaşayan ve aile bireylerinde sağlık sorunu yaşayan öğrencilerin orta/kötü sağlık düzeyi için risk grubu olarak değerlendirmeleri bu araştırmanın en temel sonucudur.

Bu çalışmanın sonuçlarına yönelik olarak okul hemşireliği uygulamalarında aşağıdaki özellikler yönünden kullanılabilir: Okul hemşireleri öğrencilerin sağlık durumunu değerlendirirken, öğrencilerin öz bildirime dayalı sağlık düzeyini kullanması ve öğrenci sağlığını değerlendiren formlarda ailenin sağıı özelliklerinin de yer almasını sağlamalıdır. Yukarda tanımlanan risk grubundaki öğrencileri daha sık takip etmeli, bu öğrencilere sağlanan sosyal olanakların arttırılmalı, ev ziyaretleri yapılmalı, öğrenci ve okul arasındaki ilişkiyi güçlendirecek faaliyetler düzenlenmeli ve yoksul ailelere özel müdahaleler geliştirmelidir.

Okul sağlığı hemşiresi aileyi bir bütün olarak ele almalı; aileyi daha sık takip etmeli, ailede bulunan sağlık sorununun tanımlanması ve tedavisini sağlamalı, aileyi riskli davranışlardan uzak tutmalıdır. Öğrencinin sağığının geliştirilmesi ile ailenin sağıı düzeyi arasında bir ilişki olduğunu uygulamaları sırasında hep göz önünde bulundurmalıdır.

Etik Kurul Onayı: Selçuk Üniversitesi Sağlık Bilimleri Fakültesi Girişimsel Olmayan Klinik Araştırmalar Etik Kurulu Başkanlığı'ndan (2014/85) alınmıştır.

Çıkar Çatışması: Bildirilmemiştir.

Finansal Destek: Yoktur.

Katılımcı Onamı: Öğrencilerden bilgilendirilmiş onam alınmıştır.

Yazar katkıları:

Araştırma dizaynı: EA, DKT

Veri Toplama: EA, DKT

Makale Yazımı: EA, DKT

Teşekkür

Çalışmaya katılan bütün öğrencilere teşekkür ederiz.

Ethics Committee Approval: Approval was obtained from Non-interventional Clinical Research Ethics Committee of Health Sciences Faculty of Selcuk University.

Confict of Interest: Not reported.

Funding: None.

Exhibitor Consent: Informed consent was obtained from students.

Author contributions:

Study design: EA, DKT

Data collection: EA, DKT

Drafting manuscript: EA, DKT

Acknowledgement: We would like to thank all the students.

\section{KAYNAKLAR}

1. Velioğlu P. Hemşirelikte Kavram ve Kuramlar. Florence Nightingale Hemşirelik Yüksek Okulu, İstanbul. 1999:78-92.

2. Bolsoy N, Sevil Ü. Sağlık hastalık ve kültür etkileşimi. Atatürk Üniversitesi HYO Dergisi. 2006;9(3):78-87.

3. Birol L. Hemşirelik süreci. İzmir: Etki Matbaacılık Yayıncilık; 2004.

4. Erengin H, Dedeoğlu N. Sağlığı ölçmenin kolay bir yolu algılanan sağlık. Toplum ve Hekim Dergisi. 1997;12(77):11-6.

5. Ayrancı Ü. Eskisehir'de yaşlıların sosyoekonomik özellikleri ve sağlık durumları. Sürekli Tıp Eğitimi Dergisi. 2005;14(5):113.

6. Gönülal A. Yaşılırın sağlığı geliştirme davranışları ve etkileyen etmenlerin incelenmesi [Yüksek Lisans Tezi]. İzmir: Dokuz Eylül Üniversitesi Sağlık Bilimleri Enstitüsü; 2005.

7. Üstün B, Bahar Z, Partlak N, Akgün E, Öztürk M. Bakımevinde yaşayan yaşlılarda depresyon ve etkileyen faktörlerin incelenmesi. Zonguldak Sağlık Yüksekokulu Sağlık Eğitim Araştırma Dergisi. 2005;1(1):26-33.

8. Pender N, Barkauskas V, Hayman L, Rice V, Anderson E. Health promotion and disease prevention: Toward 
excellence in nursing practise and education. Nursing Outlook. 1992;40(3):106-12.

9. Bottorff JL, Johnson JL, Ratner PA, Hayduk LA. The effects of cognitive-perceptual factors on health promotion behavior maintenance. Nursing research. 1996;45(1):30-6.

10. Hack M, Schluchter M, Forrest CB, Taylor HG, Drotar $D$, Holmbeck G, et al. Self-reported adolescent health status of extremely low birth weight children born 1992-1995. Pediatrics. 2012;130(1):46-53.

11. Jeannin A, Narring F, Tschumper A, Bonivento LI, Addor V, Butikofer A, et al. Self-reported health needs and use of primary health care services by adolescents enrolled in post-mandatory schools or vocational training programmes in Switzerland. Swiss Med Wkly. 2005;135(1-2):11-8.

12. Riley A. Evidence that school-age children can selfreport on their health. Ambulatory Pediatrics 2004;4:371-76.

13. Van Dijk A, McGrath P, Pickett W, Van Den Kherkof E. Pain and self-reported health in Canadian children. Pain Res Manage. 2008;13(5):407-11.

14. Şenol Y, Belek i. Antalya'nın iki mahallesinde bir araştırma: Sağlıkta eşitsizlik ve iki yıllık değişim sonuçları. Sağlık ve Toplum Dergisi. 2002;12(3):32-9.

15. Özcebe H. Ankara Gülveren sağlık ocağı bölgesi Anadolu mahallesinde 65 yaş ve üzeri nüfusun sağlık hizmeti kullanımının değerlendirilmesi. Geriatri. 2003;6(1):22-6.

16. Vissandjee B, Desmeules M, Cao Z, Abdool S. Integrating socio-economic determinants of Canadian women's health. BMC Women's Health. 2004;4(1):34-3.

17. Ahmad K, Jafar TH, Chaturvedi N. Self-rated health in Pakistan: results of a national health survey. BMC Public Health. 2005;5:51.

18. Al-Windi A. The relations between symptoms, somatic and psychiatric conditions, life satisfaction and perceived health. A primary care based study. Health and quality of life outcomes. 2005;3:28.

19. Erci B, Kılıç D, Aylaz R, Tanrıverdi G, Aydın i, Güngörmüş Z, et al. Halk Sağlığı Hemşireliği. Erci B, editor. Sözkesen Matbaası, Ankara. 2014.

20. Tschumper A, Bütikofer A, Alsaker F, Inderwildi B. Self-reported health needs and use of primary health care services by adolescents enrolled in postmandatory schools or vocational training programmes in Switzerland. Swiss Medical Weekly. 2005;135:11-8.

21. Lemeshow S, Hosmer D, Klar J, Iwanga S. Under the title adequacy of sample size in health studies by World Health Organization. Ankara: Hacettepe Taş. 2000.

22. Kucuk EE. Psychological resilience and health perception among adolescents and related factors. Medicine. 2017;6(3):504-9.

23. Yılmaz E, Yılmaz E, Karaca F. Üniversite öğrencilerinin sosyal destek ve yalnızlık düzeylerinin incelenmesi. Genel Tıp Dergisi. 2008;18(2):71-9.
24. Çivitçi A. İlköğretim öğrencilerinde yaşam doyumu bazı kişisel ve ailesel özelliklerin rolü. Eğitim Fakültesi Dergisi. 2009;22(1):29-52.

25. Penbegül N, Celik H, Palanci Y, Yildirim K, Atar M, Hatipoglu NK. Prevalence of enuresis nocturna among primary school children living in Diyarbakır. Türk Üroloji Dergisi/Turkish Journal of Urology. 2013;39(2):101-5.

26. Topses M. Eğitim düzeyi ve kardeş sayısının suç davranışıyla ilişkisi: Çanakkale E tipi kapalı ceza infaz kurumu örneği. International Journal of Social Science. 2013;6(3):701-13.

27. Ahmed SM, Rana AK, Chowdhury M, Bhuiya A. Measuring perceived health outcomes in nonwestern culture: does SF-36 have a place? Journal of health, population, and nutrition. 2002;20(4):334-42.

28. Bingöl G, Gebeş R, Yavuz R. Amasya Sağlık Yüksekokulu öğrencilerinin genel sağlık durumlarının bazı değişkenlere göre incelenmesi. Göztepe Tıp Dergisi. 2012;27(3):106-11.

29. Yanbastı G. Kişilik kuramları ders kitabı, 2. baskı. İmir: Ege Üniversitesi Edebiyat Fakültesi Yayınları; 1996.

30. Manderbacka K, Lahelma F, Martikainen P. Examining the continuity of self-rated health. International Journal Of Epidemiology. 1998;27:20813.

31. Goldberg P, Gueguen A, Schmaus A, Nakache JP, Goldberg $M$. Longitudinal study of associations between perceived health status and self reported diseases in the French Gazel cohort. Journal of Epidemiology and Community Health. 2001;55(4):233-8.

32. Mickey $T$, Trockel'ın M, Michael D, Barnes $P$, Dennis L. Health-related variables and academic performance among first-year college students: implications for sleep and other behaviors. Journal of American College Health. 2000;49(3):125-31.

33. Dwyer T, Sallis J, Blizzard L, Lazarus R, Dean K. Relation of academic performance to physical activity and fitness in children. Pediatric Exercise Science. 2001(13):225-37.

34. Geierstanger S, Amaral G, Mansour M, Walters S. School based health centers and academic performance: Research, challenges, and recommendations. Journal of School Health. 2004;74(9):347-52.

35. Kesgin MT. Çocukların Sigaranın Zararlarından Korunması: Halk Sağlığı Hemşiresi ve Öncelikli Sorumluluklar. Hacettepe Üniversitesi Hemşirelik Fakültesi Dergisi. 2012;19(1):90-6.

36. Erdil Z. Sosyoekonomik olarak risk altında bulunan çocuklara yönelik erken müdahale programları ve akademik başarı ilişkisi. Hacettepe Üniversitesi Hemşirelik Fakültesi Dergisi. 2010;17(1):72-8.

37. Yen I, Kaplan G. Poverty area residence and changes in depression and perceived health status: Evidence from the Alamada country. International Journal of Epidemiology. 1999;28(1):90-4. 
38. Sturm R, Carole R. Relations of income inequality and family income to chronic medical conditions and mental health disorders. National Survey In USA, BMJ. 2002;24(5):20-3.

39. Iancu I, Horesh N, Lepkifker E, Drory Y. An epidemiological study of depressive symptomatology among Israeli adults: prevalence of depressive symptoms and demographic risk factors. The Israel Journal of Psychiatry and Related Sciences. 2003;40(2):82-9.

40. Belek i. Sağlıktaki eşitsizliklerin değişimi Antalya'da beş yıllık bir araştırma. Toplum ve Hekim Dergisi. 2004;19(2):92-100.

41. Szaflarski M, Cubbins L. Self-reported health in Poland and the United States: a comparative analysis of demographic, family and socioeconomic influences, health: An interdisciplinary journal for the social study of health. Illness and Medicine. 2004;8(1):5-31.

42. Özdel L, Bostancı M, Özdel O. Üniversite öğrencilerinde depresif belirtiler ve sosyodemografik özelliklerle ilişkisi. Anadolu Psikiyatri Dergisi 2002;3(3):155-61.

43. Demirüstü C, Binboğa $D$, Öner S. Üniversite öğrencilerinin genel sağlık anketi skorları ve stresle baş etme yöntemleri arasındaki ilişki. Türkiye Klinikleri Dergisi. 2009;29(2):70-6.

44. Koçoğlu D, Akın B. Sosyoekonomik eşitsizliklerin sağlıklı yaşam biçimi davranışları ve yaşam kalitesi ile ilişkisi Dokuz Eylül Üniversitesi Hemşirelik Yüksekokulu Elektronik Dergisi. 2009;2(4):145-54.

45. Barr AB. Family socioeconomic status, family health, and changes in students' math achievement across high school: A mediational model. Soc Sci Med. 2015;140:27-34.

46. Şahin B. Algılanan sağlık statüsünün ölçümü yoluyla tıbbi müdahalelerin değerlendirilmesi: Bypass ameliyatı olan koroner arter hastaları üzerine bir araştırma. Toplum ve Hekim Dergisi. 1997;12(82):1423.

47. Lahey B, Russo M, Walker J. Personalitycharacteristics of the mothers of children with disruptivebehavior disorders. Consult Clin Psychol. 1989(57):512-5.

48. Toros F, Tot Ş, Bozlu M, Okyay $Y$, Çamdeviren $H$. Dikkat eksikliği hiperaktivite bozukluğu ve primer enürezis noktürnalı çocukların annelerindeki psikiyatrik belirtiler ve yetiyitimi. Klinik Psikiyatri. 2003(6):135-40.

49. Özdal F, Aral N. Baba yoksunu olan ve anne-babası ile yaşayan çocukların kaygı düzeylerinin incelenmesi.
Gazi Üniversitesi Kırşehir Eğitim Fakültesi. 2005;6(2):255-67.

50. Flouri E, Buchanan A. What predicts fathers' involvement with their children? A prospective study of intact families. British Journal of Developmental Psychology. 2003;21(1):81-97.

51. Karabekiroğlu K, Rodopman Arman A, Berkem M. Erken çocukluk dönemi psikiyatrik sorunları ile ebeveyn depresyonu arasındaki ilişki: cinsiyetin rolü. Çocuk ve Gençlik ruh sağlığı dergisi. 2008;15(2):7586.

52. Zeltzer L, Dolgin M, Sahler O. Sibling adaptation to childhood cancer collaborative study: health outcomes of siblings of children with cancer. Med Pediatr Oncol. 1996(27):98-107.

53. Baran A, Kalınkara V, Aral N, Akın G, Baran G, Özkan Y. Yaşı ve aile ilişkileri. Ankara: T.C. Başbakanlık Aile ve Sosyal Araştırmalar Genel Müdürlüğü, Genel Yayın No:127; 2005.

54. Torsheim $T$, Nygren JM, Rasmussen M, Arnarsson $A M$, Bendtsen $P$, Schnohr $C W$ ve ark. Social inequalities in self-rated health: A comparative crossnational study among 32,560 Nordic adolescents. Scandinavian journal of public health. 2018;46(1):150-6 